\title{
DISTRIBUTION OF HEAVY METALS IN THE TOPSOIL OF AGRICULTURAL LAND IN NAM DINH PROVINCE, VIETNAM
}

\author{
NGUYen, T. T. H. ${ }^{1 *}$-VuONG, H. N. ${ }^{1}-$ ZHANG, W. G. ${ }^{2}-$ LAI, V. C. ${ }^{1}-$ NGUYEN, V. H. ${ }^{1}-$ LE, B. B. ${ }^{1}$ \\ - NGUYEN, P. T. ${ }^{1}-$ TRAN, T. N. ${ }^{1}$ \\ ${ }^{1}$ Institute of Geography, Vietnam Academy of Science and Technology, A27-No 18, Hoang Quoc \\ Viet Street, Cau Giay District, Hanoi, Vietnam \\ ${ }^{2}$ State Key Laboratory of Estuarine and Coastal Research, East China Normal University, \\ Shanghai 200062, China \\ *Corresponding author \\ e-mail:thuhienkien@yahoo.com \\ (Received $12^{\text {th }}$ May 2020; accepted $13^{\text {th }}$ Aug 2020)
}

\begin{abstract}
Surface soil samples were collected from different land use types of the agricultural land in Nam Dinh province, Vietnam to determine the level of heavy metal contamination and identifying potential sources. The farming areas of rice and cereal show similar heavy metal contents, however, the index shows that the content of heavy metals in the aquacultural area is lower compared to the other types. The mean enrichment factor $(\mathrm{EF})$ values of $\mathrm{Cr}, \mathrm{Cu}, \mathrm{Pb}$, and $\mathrm{Zn}$ are less than 1.5, suggesting that these are not a major concern in the research area; whereas, the mean EF values for $\mathrm{Cd}$ is higher than 2 and As varies from 5-20 suggest that the pollution of these heavy metals is present in agricultural soil. The data analysis indicates that $\mathrm{Cr}$ mainly originates from a natural source; $\mathrm{Cd}$ and As have a significant anthropogenic input; $\mathrm{Cd}, \mathrm{Pb}$ and $\mathrm{Zn}$ have a mixed source.
\end{abstract}

Keywords: different land use, paddy, cereal, aquaculture, environment

\section{Introduction}

Soil is widely recognized as a pool of nutrients and pollutants, and plays a critical role in socio-ecological stability and national safety (Wu et al., 2018). Human-induced increase of soil contamination with heavy metal input is noteworthy, including atmospheric deposition, irrigation, application of sewage sludge, organic manures, fertilizers, and other soil amendments (Cheng, 2003; Vodyanitskii, 2013; Hou et al., 2014). When heavy metals enter the agricultural soil, they not only degrade environmental quality but they also influence the health of people and other organisms through the food chain (Nabulo et al., 2010). Therefore, it is of great importance to study the characteristics and sources of heavy metal contamination in agricultural soil to protect the environment and human health (Huang et al., 2018; Li et al., 2018).

Agriculture plays a prominent role in Nam Dinh province, with approximately $67 \%$ of the land used for agricultural production. It is usually used for 2 paddy rice crops per year equipped with a developed irrigation system (in total $3 \%$ of the province area are covered by rivers and channels (Dao et al., 2005). Traditionally, the biggest industry is textile and garment which has been developed since 1889 with French support. The craft production in Nam Dinh, especially bronze and silver casting, has a long tradition. For example, Tong Xa village has been well known for bronze and iron casting in the Red River delta since 1200, Xuan Tien commune with bronze casting and mechanical engineering since 1535, and Van Chang village with iron, steel and aluminum foundry since 1868. According to the data provided by provincial 
government, there are a total of 71 villages that are specialized on handicraft (e.g. metalworking, food processing, salt production) up to 2018 in Nam Dinh province (Joern et al., 2013). Such production places are most often based on family enterprises located all over the village; therefore, it can be stated that living and working place are rarely distinguished (Dao and Nguyen, 2000). However, all untreated wastewater from industrial and living usages discharges directly open channels or infiltrate into the soil. Previous research shows that water channels in handicraft villages are loaded with heavy metals ( $\mathrm{Zn}, \mathrm{Pb}, \mathrm{Cu}, \mathrm{Ni}, \mathrm{Cd}, \mathrm{Cr}$, and $\mathrm{Fe}$ ) and cyanides, exceeding the limits by up to 50 times (Le et al., 2003). In recent years, with the increase in population, the industrial sector has achieved prominence. This has resulted in environmental pollution caused by manufacturing activities in industrial zones. Furthermore, the Red and Day rivers receive pollutants from upstream before running across the province. Agricultural activities in the province utilize approximately 300 tons of insecticides per year (Dao et al., 2005), which causes the water to be polluted, that is then returned to the soil via the irrigation network.

Thus far, there has been very little published information on their contaminant level and sources in Nam Dinh province. To better investigate local soil quality, we have used a combined method of enrichment factor (EF) and multivariate statistical analyses with the objectives of analyzing pollution level, characteristics of spatial distribution and identifying potential sources of heavy metals in agricultural soil.

\section{Materials and methods}

\section{Study area}

Nam Dinh $\left(19^{\circ} 52^{\prime}-20^{\circ} 30^{\prime} \mathrm{N}, 105^{\circ} 55^{\prime}-106^{\circ} 35^{\prime} \mathrm{E}\right)$ is a coastal province located to the south of Red river delta with an area of $1,652.6 \mathrm{~km}^{2}$ and population of $1,825,771$ people; population density is 1,196 people per $\mathrm{km}^{2}$. The administrative unit of this province is composed of 9 districts and one city. Nam Dinh is a tropical area experiencing monsoon with hot and humid rain. The average annual temperature is ca. $23-24^{\circ} \mathrm{C}$, and the average annual rainfall is ca. $1,700-1,800 \mathrm{~mm}$. On average, up to 250 days a year are sunny, with total sunshine hours from 1650 to $1700 \mathrm{~h}$. The province is affected by storms or tropical depressions 4 to 6 times per year.

The river and estuary systems of the Red river and its tributaries (Dao, Ninh Co, Day rivers) have greatly impacted morphological and hydrological characteristics of the region. The terrain is quite flat, gradually dipping to the sea in Northwest Southeast direction. The formation of this region was historically associated with and the evolution of the Red River Delta. It can be divided into two zones: (1) the lowlying plains with elevations of 0.2 to $3 \mathrm{~m}$ above sea level with some exceptions in the northwest (7-100 m above sea level) (Vu Ban, Y Yen, Nam Truc, Truc Ninh and Xuan Truong districts). This region has a high level of agriculture, textile and manufacturing industries; (2) the lowland coastal region including Giao Thuy, Hai Hau and Nghia Hung districts. Running from north to south, Dao river seperates the two regions. In the northern region of the province (My Loc, Y Yen, Vu Ban districts and Nam Dinh city), the water is pumped directly from stagnant canals which is not well circulated and used for irrigation purposes. In the southern region (Nam Truc, Truc Ninh, Xuan Truong, Hai Hau, Giao Thuy and Nghia Hung districts), irrigation water is taken from rivers, which is well circulated because water from upstream flows into the sea. 


\section{Samples and methods}

\section{Samples}

A total of 38 surface agricultural soil samples from different land use types were collected in May, 2018 by grid method (using $10 \times 10 \mathrm{~km}$ grid). They included 20 samples from paddy field, 12 samples from cereals soil, and 6 samples from aquaculture farm (Fig. 1 and Table 1). The samples were taken at depth of 0-20 cm with volume of $0.5 \mathrm{~kg}$ soil by using hand steel drill. Per site, two samples were taken. Samples were packed in plastic bags to send to the laboratory. All samples were dried at $40{ }^{\circ} \mathrm{C}$, then desegregated prior to analysis.

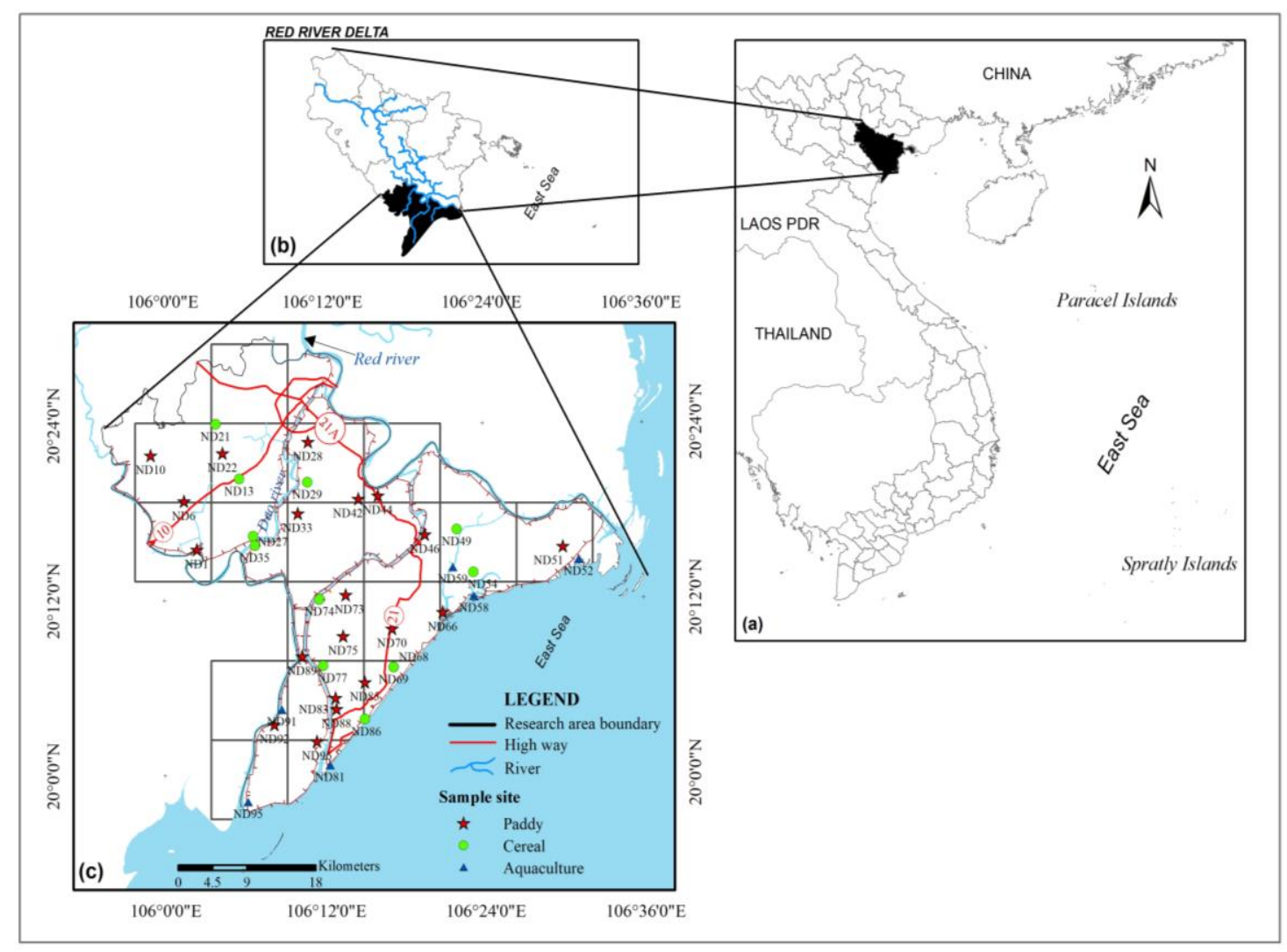

Figure 1. Map of the study area (a), Red river delta (b), with the sampling sites detailed in (c)

\section{Methods}

For heavy metal analysis, $\sim 0.1 \mathrm{~g}$ dry soil was weighed into Teflon beakers, in which a mixture of concentrated $2 \mathrm{ml} \mathrm{HF}-6 \mathrm{ml} \mathrm{HCl}-2 \mathrm{ml} \mathrm{HNO}_{3}$ were added (Elsorogy et al., 2016), a Teflon watch cover was put in place, and the sample was left at room temperature overnight. On the following day, the sample was digested using a scientific microwave system (Mars 6, USA) with the following heating program: the temperature rises from room temperature to $180{ }^{\circ} \mathrm{C}$ in $15 \mathrm{~min}$, keep at $180^{\circ} \mathrm{C}$ for decomposition for $30 \mathrm{~min}$, then let solutions cool down to room temperature again. The solution is transferred to the plastic volumetric tube and filled up to the mark by using deionized water. Heavy metals ( $\mathrm{As}, \mathrm{Cd}, \mathrm{Cr}, \mathrm{Cu}, \mathrm{Pb}$, and $\mathrm{Zn}$ ) concentration were determined by inductive couple plasma - mass spectrometry (ICP-MS, Agilent 7900). European 
commission community bureau of reference material Estuarine sediment sample identification No0087 was included for quality control. The analytical precision and error of the analysis are within $10 \%$.

Table 1. The global positioning system coordinates of the sampling points

\begin{tabular}{|c|c|c|c|c|c|c|c|c|c|}
\hline CODE & Yho & Ymi & Yse & Ydec & Xho & Xmi & Xse & Xdec & Land use type \\
\hline ND1 & 20 & 15 & 30 & 20.25833 & 106 & 2 & 27 & 106.04083 & Paddy \\
\hline ND6 & 20 & 18 & 39 & 20.31083 & 106 & 1 & 26 & 106.02389 & Paddy \\
\hline ND10 & 20 & 21 & 57 & 20.36583 & 105 & 59 & 1 & 105.98361 & Paddy \\
\hline ND13 & 20 & 20 & 18 & 20.3383 & 106 & 5 & 40 & 106.0944 & Cereal \\
\hline ND21 & 20 & 24 & 3 & 20.4008 & 106 & 3 & 55 & 106.0653 & Cereal \\
\hline ND22 & 20 & 22 & 5 & 20.36806 & 106 & 4 & 22 & 106.07278 & Paddy \\
\hline ND27 & 20 & 16 & 19 & 20.2719 & 106 & 6 & 37 & 106.1103 & Cereal \\
\hline ND28 & 20 & 22 & 49 & 20.38028 & 106 & 10 & 51 & 106.18083 & Paddy \\
\hline ND29 & 20 & 20 & 3 & 20.3342 & 106 & 10 & 48 & 106.1800 & Cereal \\
\hline ND33 & 20 & 17 & 56 & 20.29889 & 106 & 10 & 4 & 106.16778 & Paddy \\
\hline ND35 & 20 & 15 & 49 & 20.2636 & 106 & 6 & 53 & 106.1147 & Cereal \\
\hline ND42 & 20 & 18 & 54 & 20.315 & 106 & 14 & 37 & 106.24361 & Paddy \\
\hline ND44 & 20 & 19 & 7 & 20.31861 & 106 & 15 & 66 & 106.26833 & Paddy \\
\hline ND46 & 20 & 16 & 30 & 20.275 & 106 & 19 & 30 & 106.325 & Paddy \\
\hline ND49 & 20 & 16 & 46 & 20.2794 & 106 & 22 & 1 & 106.3669 & Cereal \\
\hline ND51 & 20 & 15 & 33 & 20.25917 & 106 & 30 & 0 & 106.5 & Paddy \\
\hline ND52 & 20 & 14 & 39 & 20.2442 & 106 & 31 & 11 & 106.5197 & Aquaculture \\
\hline ND54 & 20 & 13 & 50 & 20.2306 & 106 & 23 & 15 & 106.3875 & Cereal \\
\hline ND58 & 20 & 12 & 11 & 20.2031 & 106 & 23 & 17 & 106.3881 & Aquaculture \\
\hline ND59 & 20 & 14 & 10 & 20.2361 & 106 & 21 & 42 & 106.3617 & Aquaculture \\
\hline ND66 & 20 & 11 & 6 & 20.185 & 106 & 20 & 55 & 106.34861 & Paddy \\
\hline ND68 & 20 & 7 & 21 & 20.1225 & 106 & 17 & 12 & 106.2867 & Cereal \\
\hline ND69 & 20 & 7 & 21 & 20.1225 & 106 & 17 & 12 & 106.2867 & Cereal \\
\hline ND70 & 20 & 10 & 3 & 20.1675 & 106 & 17 & 1 & 106.28361 & Paddy \\
\hline ND73 & 20 & 12 & 12 & 20.20333 & 106 & 13 & 38 & 106.22722 & Paddy \\
\hline ND74 & 20 & 12 & 2 & 20.2006 & 106 & 11 & 39 & 106.1942 & Cereal \\
\hline ND75 & 20 & 9 & 30 & 20.15833 & 106 & 13 & 25 & 106.22361 & Paddy \\
\hline ND77 & 20 & 7 & 29 & 20.1247 & 106 & 11 & 55 & 106.1986 & Cereal \\
\hline ND81 & 20 & 0 & 40 & 20.0111 & 106 & 12 & 23 & 106.2064 & Aquaculture \\
\hline ND83 & 20 & 5 & 17 & 20.08806 & 106 & 12 & 49 & 106.21361 & Paddy \\
\hline ND85 & 20 & 6 & 21 & 20.10583 & 106 & 15 & 2 & 106.25056 & Paddy \\
\hline ND86 & 20 & 3 & 48 & 20.0633 & 106 & 14 & 60 & 106.2500 & Cereal \\
\hline ND88 & 20 & 4 & 31 & 20.07528 & 106 & 12 & 52 & 106.21444 & Paddy \\
\hline ND89 & 20 & 8 & 9 & 20.13583 & 106 & 10 & 20 & 106.17222 & Paddy \\
\hline ND91 & 20 & 4 & 29 & 20.0747 & 106 & 8 & 46 & 106.1461 & Cereal \\
\hline ND92 & 20 & 3 & 29 & 20.05806 & 106 & 8 & 12 & 106.13667 & Paddy \\
\hline ND95 & 19 & 57 & 0 & 19.9500 & 106 & 6 & 24 & 106.1067 & Aquaculture \\
\hline ND96 & 20 & 2 & 19 & 20.03861 & 106 & 11 & 24 & 106.19 & Paddy \\
\hline
\end{tabular}


Total organic carbon was determined by titration method using Mohr salt $\left(\mathrm{NH}_{4}\right)_{2} \mathrm{Fe}\left(\mathrm{SO}_{4}\right)_{2} .6 \mathrm{H}_{2} \mathrm{O}$ after digestion of the sample by mixture of $\mathrm{K}_{2} \mathrm{Cr}_{2} \mathrm{O}_{7}-\mathrm{H}_{2} \mathrm{SO}_{4}$, which followed the method of ISO 14235:1998. Grain-size distribution of desalted sediments was determined by wet sieving of sand and gravel and by the pipette technique for silt and clay fractions according to Vietnam Standards: Soil quality Method for determination of particle size distribution (TCVN 8567:2010).

Enrichment factor (EF) is commonly used to discern metal contamination. EF is calculated as follows (Eq. 1; Salomons and Forstner, 1984; Sinex and Wright, 1988):

$$
A=\frac{\left(\frac{M e}{A l}\right)_{\text {Sample }}}{\left(\frac{M e}{A l}\right)_{\text {Background }}}
$$

where $(\mathrm{Me} / \mathrm{Al})_{\text {sample }}$ is the metal to aluminum (Al) ratio in the samples; $(\mathrm{Me} / \mathrm{Al})_{\text {background }}$ is the metal to $\mathrm{Al}$ ratio in background. Because $\mathrm{Al}$ is one of the most abundant elements on the earth and its concentration is generally not influenced by anthropogenic sources, it is commonly used for normalization purpose (Schropp and Windom, 1988). There is little information about heavy metal background values in the Nam Dinh province. Therefore, we adopted the values of upper continental crust (Taylor and McLennan, 1995 ) as the background values, which are (in mg. $\mathrm{kg}^{-1}$ ): 80,400 for $\mathrm{Al} ; 0.098$ for $\mathrm{Cd} ; 25$ for $\mathrm{Cu} ; 20$ for $\mathrm{Pb}$, and 71 for $\mathrm{Zn}$. For $\mathrm{As}$ and $\mathrm{Cr}$, the updated values of $5.7 \mathrm{mg} \cdot \mathrm{kg}^{-1}$ and $73 \mathrm{mg} \cdot \mathrm{kg}^{1}$, respectively were used (Hu and Gao, 2008). This approach has been widely used to determine the source heavy metal pollution in soil environment (José et al., 2017; Dragović and Mihailović, 2009; Loska et al., 2004).

Multivariate statistical methods such as cluster analysis (CA), principal component analysis (PCA) provide a classification tool based on the relationship between different metals in different sampling points, which can be used to distinguish between the natural and anthropogenic sources of heavy metal (Wang et al., 2019b; Han et al., 2006; Wu and Zhang, 2010; Nguyen et al., 2016a).

Cluster analysis was performed on the heavy metal concentrations and soil properties using SPSS 20.0 software (IBM, USA) using nearest neighbor linkage method based on correlation coefficients. The distance cluster represents the degree of association between elements, the smaller the value on the distance cluster, the more significant the association (Luo et al., 2007).

Principal component analysis using SPSS 20.0 software (IBM, USA) was used in the data set to determine the relationships and common origins between metals. PCA was performed with Varimax rotation with Kaiser Normalization, which facilitated the interpretation of output by minimizing the number of variables that loaded high loads on each component. In this study, all principal factors extracted from the variables were retained with eigenvalues $>1.0$, as suggested by the Kaiser criterion (Kaiser, 1960). According to the results obtained from PCA, possible sources of chemical elements were interpreted (Lu et al., 2012).

In this paper, Inverse Distance Weighted which one of tool on ArcGIS 10.5 software is used for interpolating map of heavy metal content. The reclassify the results following the method of equal values to show the distribution of each heavy metal. 


\section{Results and discussion}

\section{Soil properties in different land use types}

Soil properties that could influence the accumulation ability of heavy metals include total organic carbon (TOC), $\mathrm{pH}$, soil grain size, and concentration of aluminum ( $\mathrm{Al}$ ). The variation of these properties in the 38 samples is presented in Table 2. From Table 2 we can recognize that TOC concentration varied among the land use types in Nam Dinh province. Highest TOC content occurred in the paddy soil $\left(\mathrm{TOC}_{\text {mean }}=2.99 \%\right)$, which might be related to the tradition of applying organic fertilizers in rice production in this area (Nguyen et al., 2018). The second highest TOC content occurred in the cereals soil $\left(\mathrm{TOC}_{\text {mean }}=1.09 \%\right)$, and the least in the aquaculture $\left(\mathrm{TOC}_{\text {mean }}=0.58 \%\right)$.

The mean $\mathrm{pH}$ value in the studied area was 6.08 . The $\mathrm{pH}$ values of the sampling sites ranged from 3.87 to 8.05 , from extremely acidic to moderately alkaline. According to land use type, the mean $\mathrm{pH}$ of paddy soil was $5.6 \pm 1.06$, close to moderately acidic; the mean $\mathrm{pH}$ of cereal soil was $6.8 \pm 1.08$, near neutral; the mean $\mathrm{pH}$ of aquaculture soil was $7.82 \pm 0.15$, close to slightly alkaline.

Soil grain size varies in each land use type, with sand always being dominant and the mean clay percentage in different types of land use decreases in the order of paddy soil > cereal soil > aquaculture soil in the study area.

Table 2. Soil properties of samples from different land use types

\begin{tabular}{|c|c|c|c|c|c|c|c|}
\hline \multirow{2}{*}{ Land use type } & \multirow{2}{*}{ Parameter } & \multirow{2}{*}{ pH } & \multirow{2}{*}{ TOC (\%) } & \multicolumn{3}{|c|}{ Grain size } & \multirow{2}{*}{$\begin{array}{c}\text { Al } \\
\left(\mathrm{mg}^{-k g^{-1}}\right)\end{array}$} \\
\hline & & & & Sand $(\%)$ & Silt (\%) & Clay (\%) & \\
\hline \multirow{4}{*}{$\begin{array}{l}\text { Paddy } \\
\mathrm{n}=20\end{array}$} & Mean & 5.6 & 2.99 & 34.76 & 36.6 & 28.64 & 46524.48 \\
\hline & Max & 8.05 & 7.75 & 92.78 & 57.8 & 48.34 & 118010.8 \\
\hline & Min & 3.87 & 0.22 & 6.16 & 2.52 & 4.12 & 2463 \\
\hline & $\mathrm{SD}$ & 1.06 & 1.37 & 23.48 & 13.81 & 11.34 & 25161.74 \\
\hline \multirow{4}{*}{$\begin{array}{l}\text { Cereal } \\
\mathrm{n}=12\end{array}$} & Mean & 6.8 & 1.09 & 66.78 & 18.23 & 14.98 & 34433.53 \\
\hline & Max & 7.83 & 3.08 & 98.18 & 41.5 & 35.98 & 77992.67 \\
\hline & Min & 4.04 & 0.12 & 23.86 & 0 & 1.82 & 5710.1 \\
\hline & $\mathrm{SD}$ & 1.08 & 0.71 & 25.59 & 14.43 & 11.64 & 22384.12 \\
\hline \multirow{4}{*}{$\begin{array}{l}\text { Aquaculture } \\
n=6\end{array}$} & Mean & 7.82 & 0.58 & 72.32 & 14.19 & 13.49 & 49716.46 \\
\hline & Max & 8.05 & 1 & 93.52 & 38 & 22.26 & 85773.7 \\
\hline & Min & 7.59 & 0.06 & 41.78 & 0 & 6.48 & 12825 \\
\hline & $\mathrm{SD}$ & 0.15 & 0.39 & 18.87 & 13.12 & 6.32 & 28360.69 \\
\hline \multirow{4}{*}{$\begin{array}{c}\text { All samples } \\
\mathrm{n}=38\end{array}$} & Mean & 6.08 & 2.34 & 45.45 & 30.38 & 24.17 & 44181.78 \\
\hline & $\operatorname{Max}$ & 8.05 & 7.75 & 98.18 & 57.8 & 48.34 & 118010.8 \\
\hline & Min & 3.87 & 0.06 & 6.16 & 0 & 1.82 & 2463 \\
\hline & $\mathrm{SD}$ & 1.21 & 1.53 & 28.18 & 16.54 & 12.95 & 25149.49 \\
\hline
\end{tabular}

\section{Heavy metal concentration in agricultural soil in Nam Dinh province}

Heavy metal concentrations in agricultural soil in Nam Dinh province are summarized in Table 3 and Figures 2-9. The mean concentrations of heavy metals in agricultural soil are in decreasing order of $\mathrm{Zn}>\mathrm{Cr}>\mathrm{Cu}>\mathrm{Pb}>\mathrm{As}>\mathrm{Cd}$. A comparison of the concentrations of heavy metals in the studied soil with the documented data from 
agricultural soil areas in Vietnam show that the contents of $\mathrm{As}, \mathrm{Cr}$ and $\mathrm{Zn}$ are close to previously reported result in the Ba Lat estuary of the Red River (located in Giao Thuy and Xuan Truong districts of Nam Dinh province), while the contents of $\mathrm{Cu}$ and $\mathrm{Pb}$ are lower 2 to 3 times. In comparison with heavy metal concentration in agricultural soil of Duy Tien district, Ha Nam province, which is also located in Red River delta, we found that the contents of $\mathrm{As}$ and $\mathrm{Pb}$ in this study are higher 2 and 2.5 times, respectively, while the contents of $\mathrm{Cu}$ and $\mathrm{Zn}$ are lower. The concentration of $\mathrm{As}, \mathrm{Cd}$ is higher 5.3 and 1.2 times, respectively while the concentration of $\mathrm{Cr}, \mathrm{Cu}, \mathrm{Pb}$ and $\mathrm{Zn}$ is lower in comparison to their counterparts in the upper continental crust.

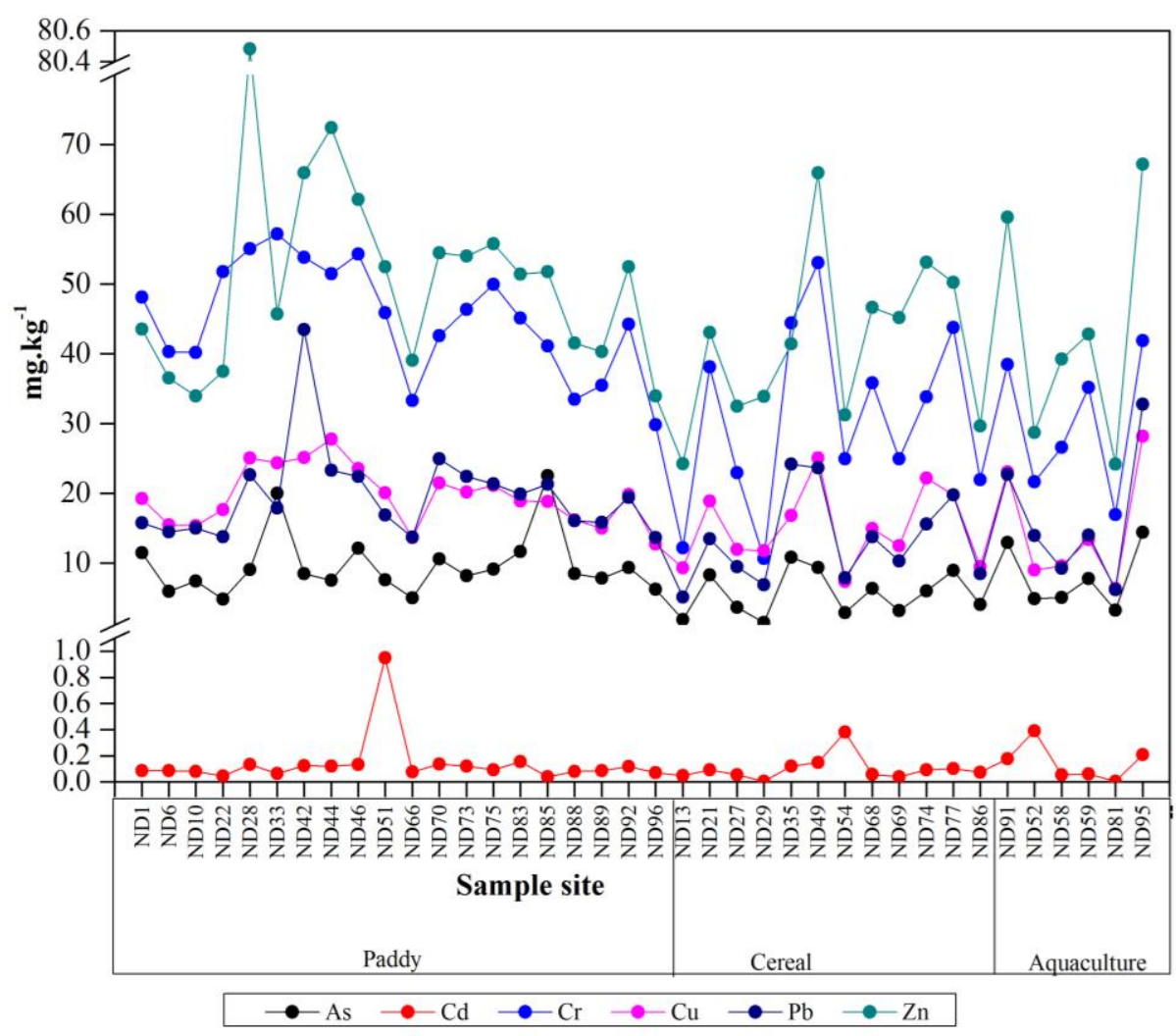

Figure 2. Spatial variations of heavy metals of the agricultural soil in Nam Dinh province

Concentrations of metals in soil from different land uses are also presented in Table 3 and Figure 3. In general, paddy soil samples have the highest heavy metal concentration, which was followed by cereal soil samples and aquaculture soil samples. The concentrations of $\mathrm{Cd}$ do not exhibit a clear trend. The hotpots of higher $\mathrm{Cd}$ contents occurred in Giao Thuy district.

\section{Assessment of heavy metal pollution}

The enrichment factor (EF) values can give an insight into differentiating an anthropogenic source from a natural origin. Typically, an EF value of $<1.5$ suggests a dominance of natural sources (Zhang and Liu, 2002). Further, EF values can also assist the determination of the degree of metal contamination. Five contamination categories are recognized on the basis of the enrichment factor (Sutherland, 2000; Loska and Wiechula, 2003) (Table 4). 
Table 3. Heavy metal concentrations in the topsoil of the agricultural soil in Nam Dinh province, Vietnam

\begin{tabular}{|c|c|c|c|c|c|c|c|c|c|}
\hline & As & Cd & $\mathrm{Cr}$ & $\mathbf{C u}$ & $\mathbf{P b}$ & Zn & Mn & Al & Reference \\
\hline \multicolumn{7}{|c|}{$\left(\mathrm{mg} \cdot \mathrm{kg}^{-1}\right)$} & \multicolumn{2}{|c|}{$\%$} & \\
\hline \multicolumn{9}{|c|}{ Nam Dinh } & \multirow{3}{*}{ This study } \\
\hline Mean \pm SD & $7.99 \pm 4.36$ & $0.12 \pm 0.16$ & $37.82 \pm 12.33$ & $16.96 \pm 5.99$ & $16.78 \pm 7.53$ & $45.74 \pm 13.49$ & $0.06 \pm 0.03$ & $6.01 \pm 2.79$ & \\
\hline Min-Max & $1.47-22.56$ & 0.01-0.95 & $10.68-57.20$ & $6.37-28.19$ & $5.13-43.51$ & $24.17-80.48$ & $0.01-0.17$ & $1.60-11.80$ & \\
\hline \multicolumn{9}{|c|}{ Ba Lat } & \multirow{3}{*}{$\begin{array}{l}\text { Nguyen et } \\
\text { al., 2016b }\end{array}$} \\
\hline Mean & 14.5 & & & & 43.4 & 59.5 & & & \\
\hline Min-Max & $6.9-31.0$ & $0.05-0.43$ & $26.9-63.1$ & $14.9-67.2$ & $24.2-78.3$ & $32.1-92.4$ & & & \\
\hline \multicolumn{9}{|c|}{ Duy Tien, Ha Nam } & \multirow{3}{*}{$\begin{array}{l}\text { Phan and } \\
\text { Tran, } 2016\end{array}$} \\
\hline Mean & 3.27 & 0.52 & & 39.48 & 8.52 & 93.06 & & & \\
\hline Min-Max & $2.56-5.15$ & $0.28-0.86$ & & $27.61-55.28$ & $8.11-8.61$ & $65.81-123.51$ & & & \\
\hline $\begin{array}{c}\text { Upper } \\
\text { continental } \\
\text { crust (UCC) }\end{array}$ & 1.5 & 0.098 & 85 & 25 & 20 & 71 & & & $\begin{array}{c}\text { Taylor and } \\
\text { McLennan, } \\
1995\end{array}$ \\
\hline
\end{tabular}

Table 4. Contamination categories based on EF values

\begin{tabular}{c|c}
\hline $\mathrm{EF}<2$ & Deficiency to minimal enrichment \\
\hline $\mathrm{EF}=2-5$ & Moderate enrichment \\
\hline $\mathrm{EF}=5-20$ & Significant enrichment \\
\hline $\mathrm{EF}=20-40$ & Very high enrichment \\
\hline $\mathrm{EF}>40$ & Extremely high enrichment \\
\hline
\end{tabular}
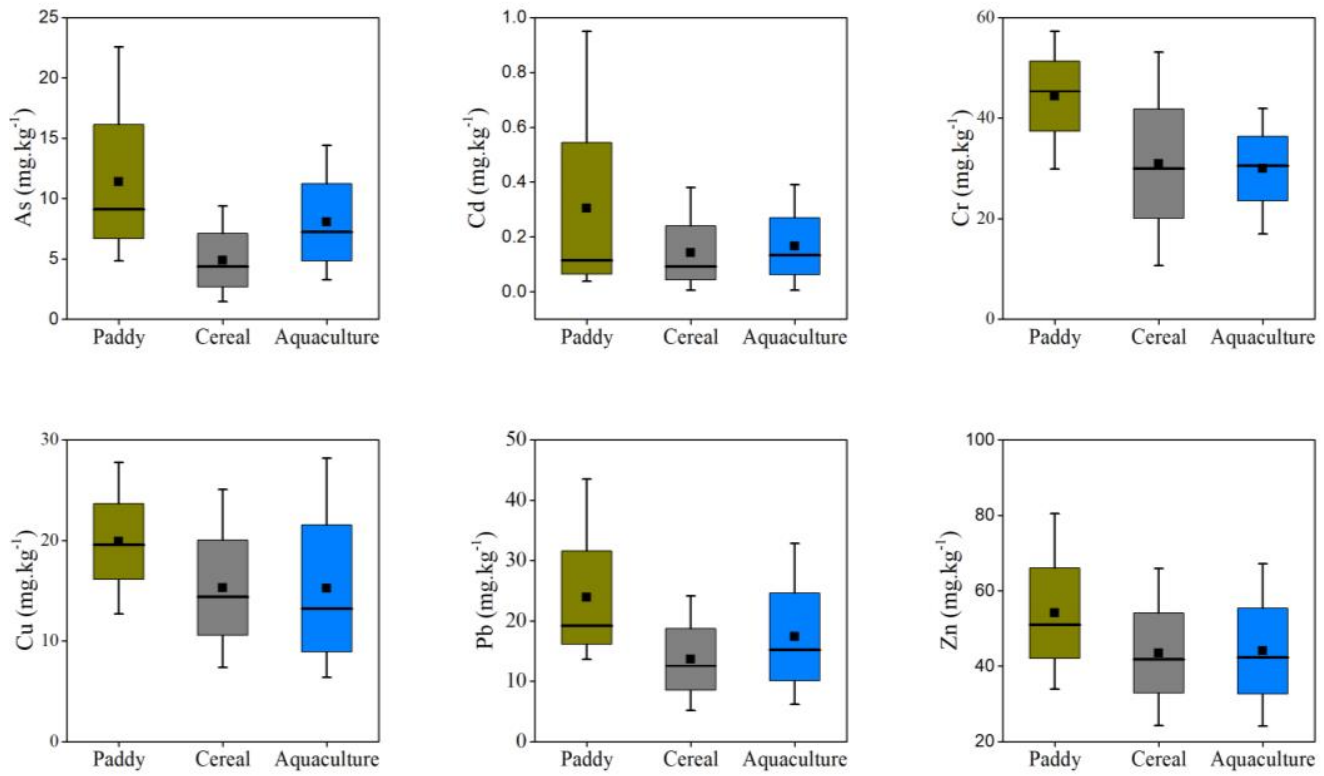

Figure 3. Box plot of the heavy metal concentrations in soil samples of the three land use types. The black solid line inside the box is the median value, the black rhombus is the mean value, and the black vertical line is individual samples 


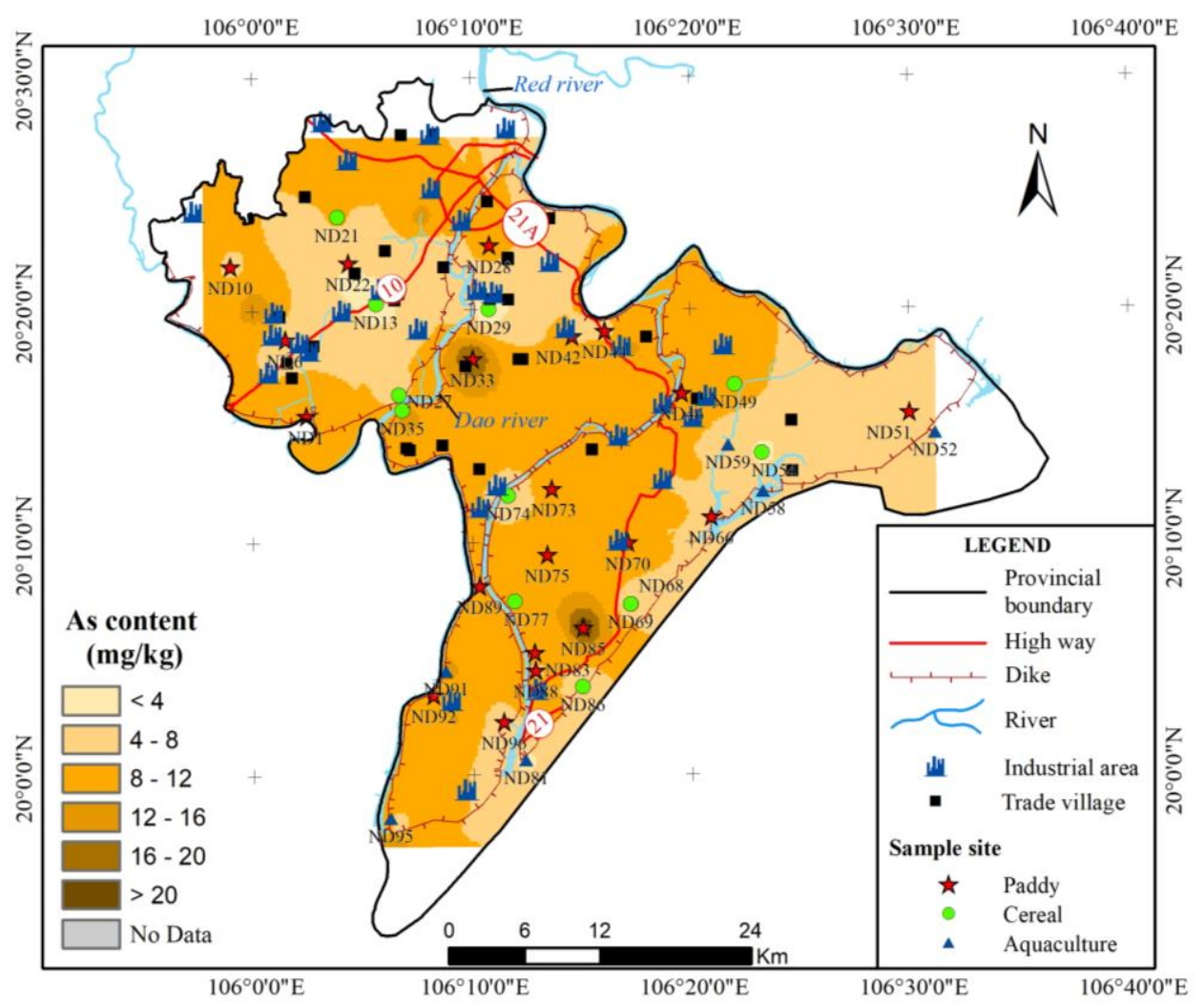

Figure 4. Distribution of As in the topsoil of the agricultural soil in Nam Dinh province

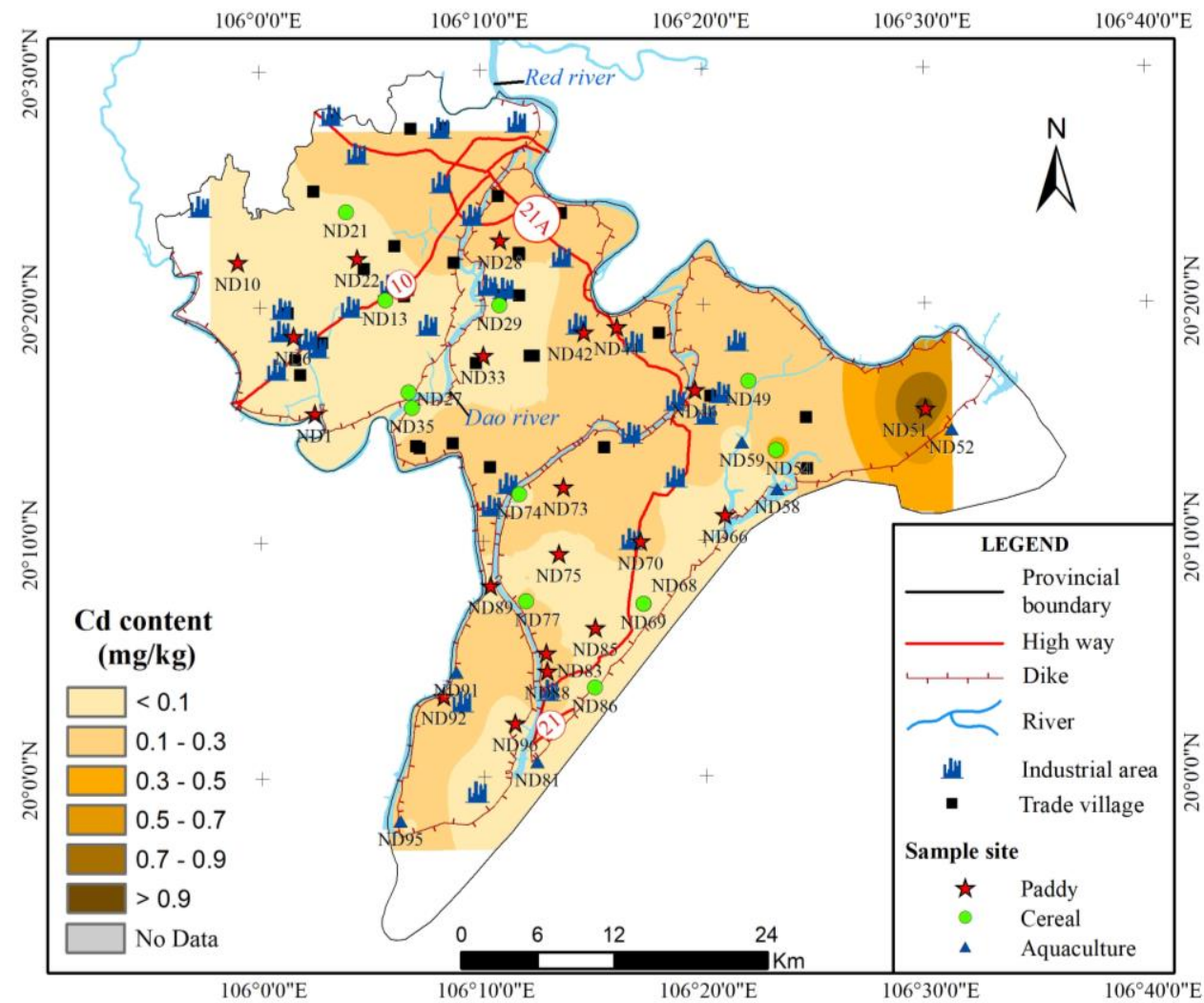

Figure 5. Distribution of Cd in the topsoil of the agricultural soil in Nam Dinh province 


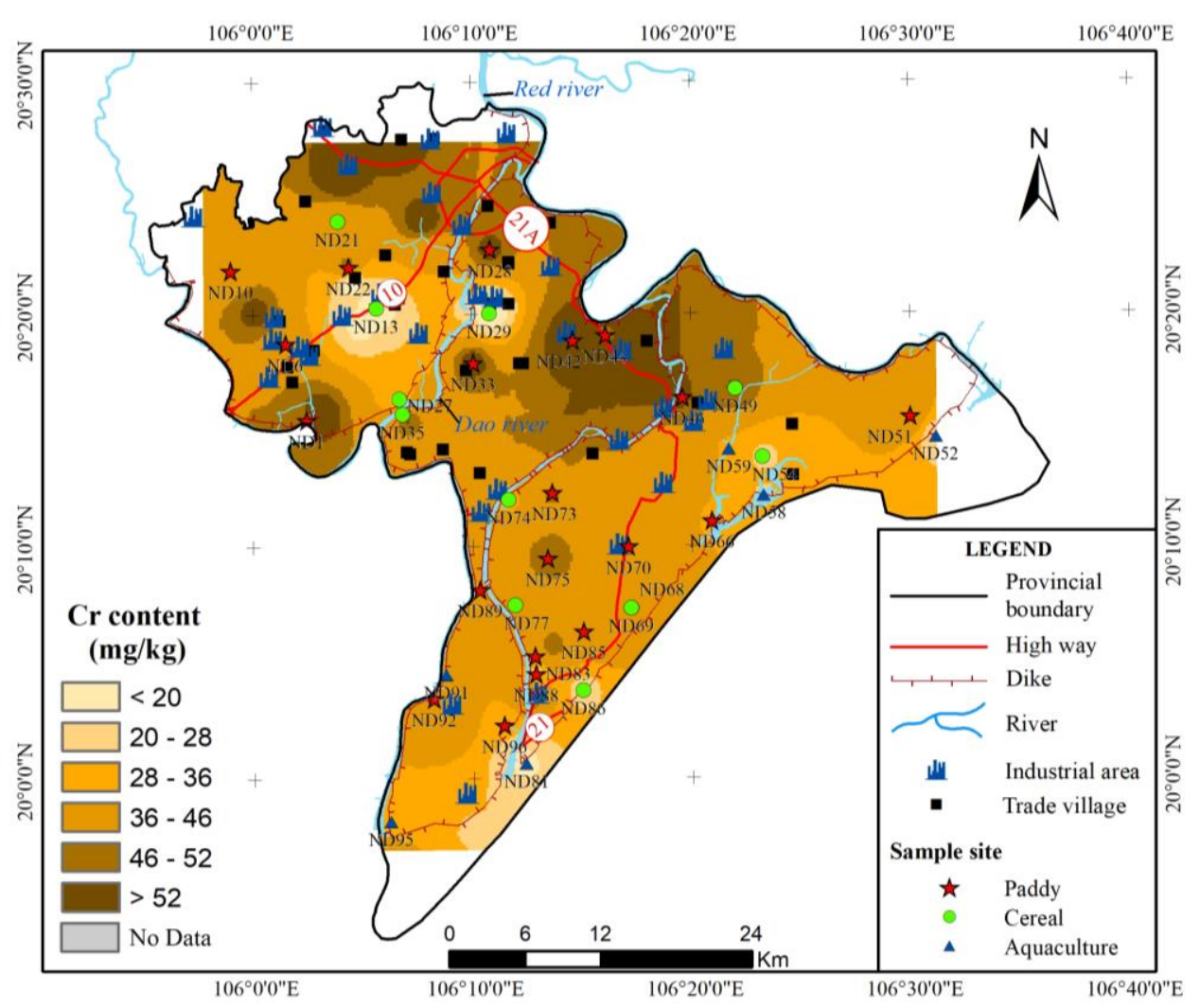

Figure 6. Distribution of $\mathrm{Cr}$ in the topsoil of the agricultural soil in Nam Dinh province

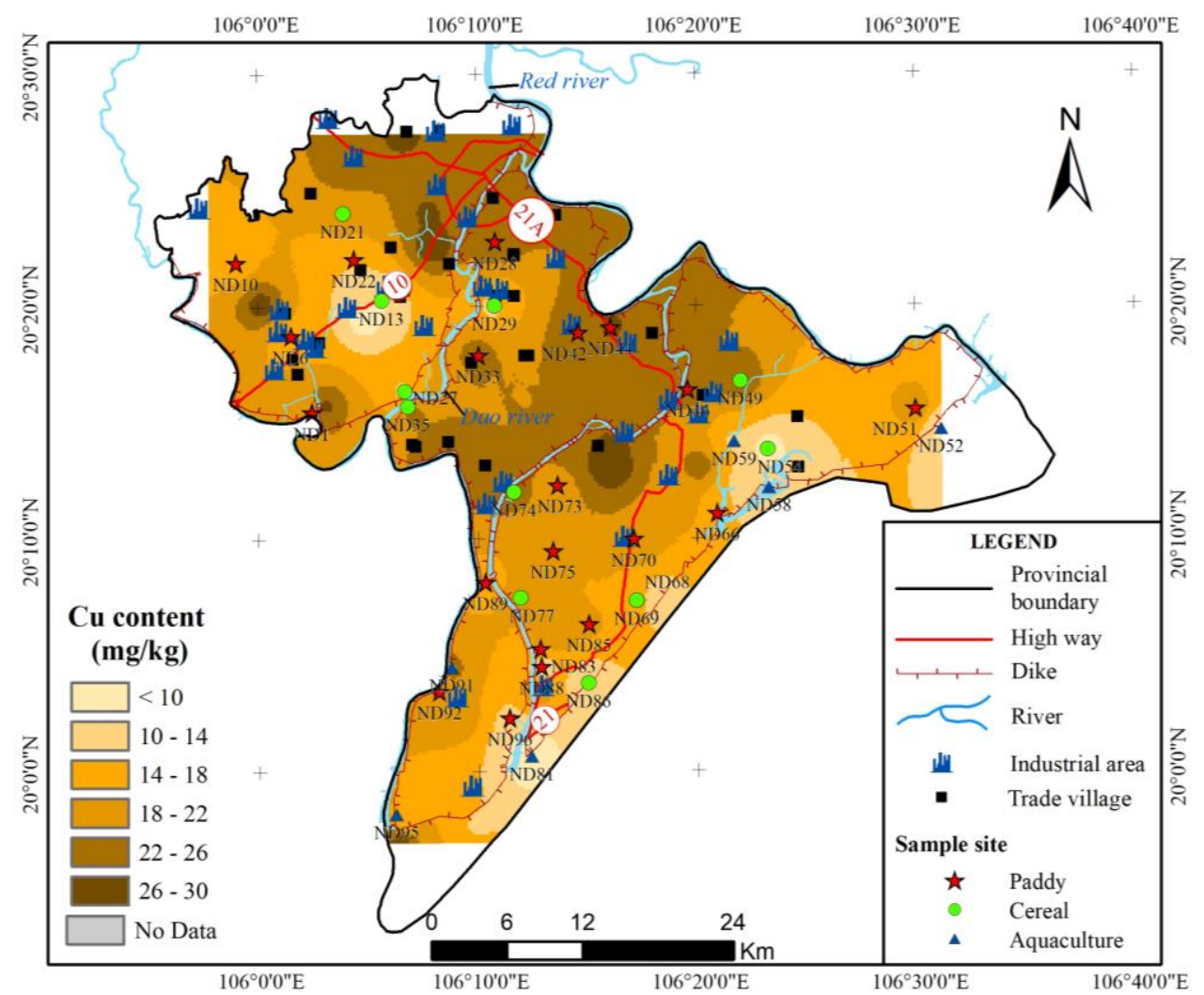

Figure 7. Distribution of $\mathrm{Cu}$ in the topsoil of the agricultural soil in Nam Dinh province 


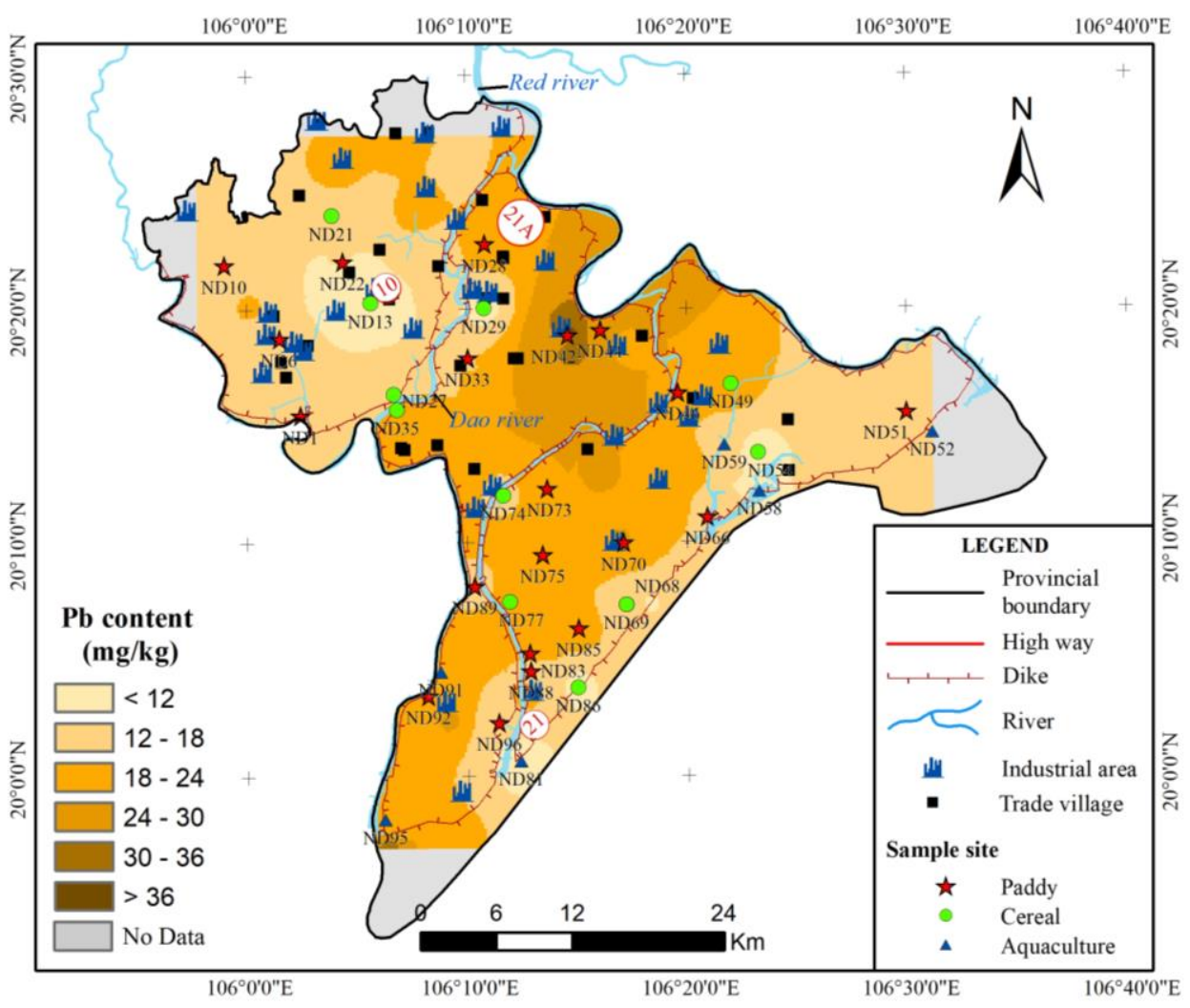

Figure 8. Distribution of $\mathrm{Pb}$ in the topsoil of the agricultural soil in Nam Dinh province

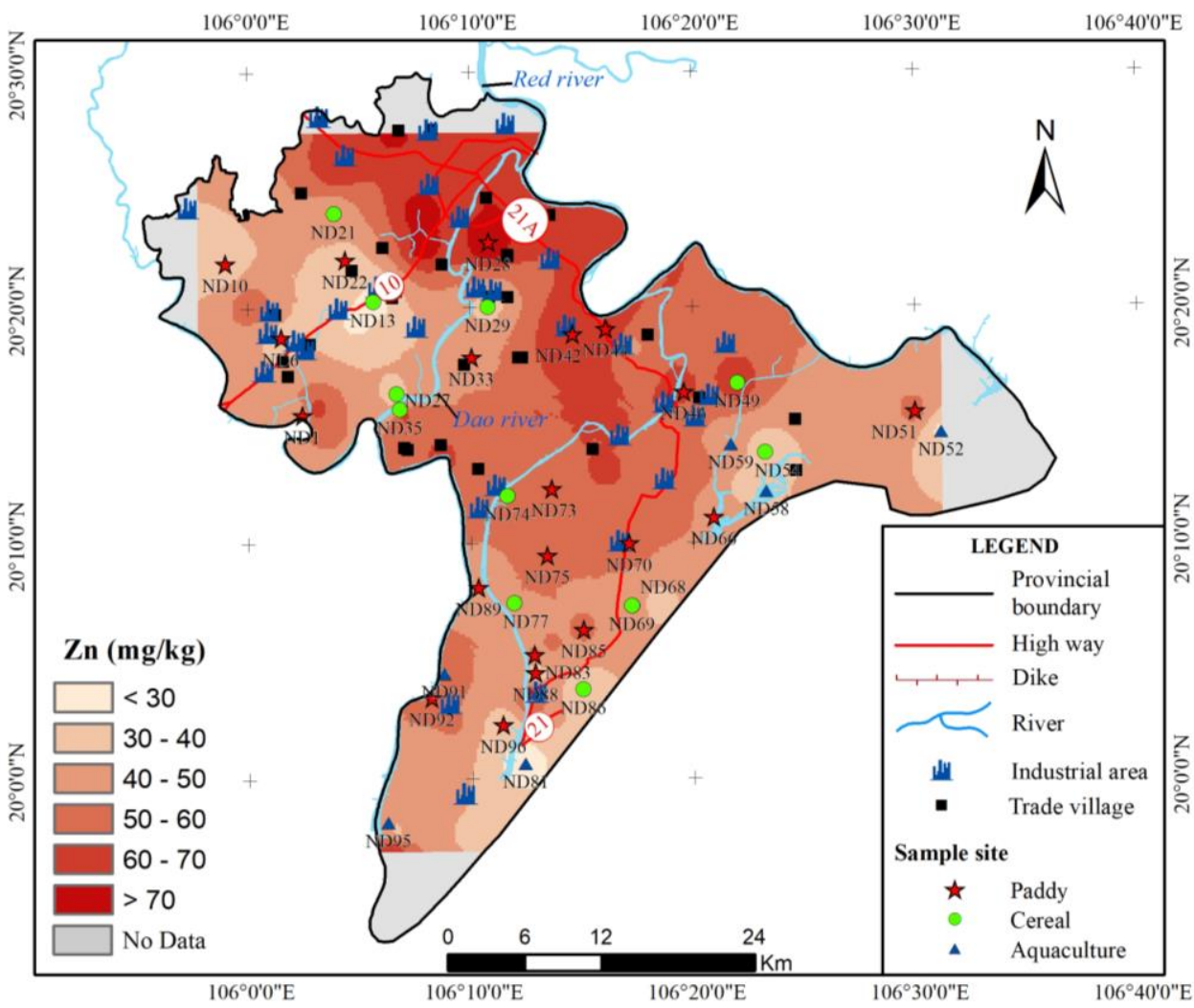

Figure 9. Distribution of Zn in the topsoil of the agricultural soil in Nam Dinh province 
The enrichment factors in agricultural soils in Nam Dinh province are shown in Figure 10 and Table 5. It is clear that $\mathrm{Cr}, \mathrm{Cu}, \mathrm{Pb}$, and $\mathrm{Zn}$ have a mean EF less than 1.5, confirming their mainly natural sources except some sites have EF values higher than 1.5 (e.g. ND29, ND35, ND73, ND96). On the other hand, the mean EF values of As and Cd are higher than 2, indicating existence of heavy metal contamination in agricultural soil of Nam Dinh province (Han et al., 2006). In this study, the mean EF values were ranked in the order of $\mathrm{As}>\mathrm{Cd}>\mathrm{Pb}>\mathrm{Cu}>\mathrm{Zn}>\mathrm{Cr}$. The element $\mathrm{Cd}$ has mean EF value between 2 and 5, which was classified as moderately contaminated. The mean EF values of As lie between 5 and 20, which means a significant contamination in this study area.
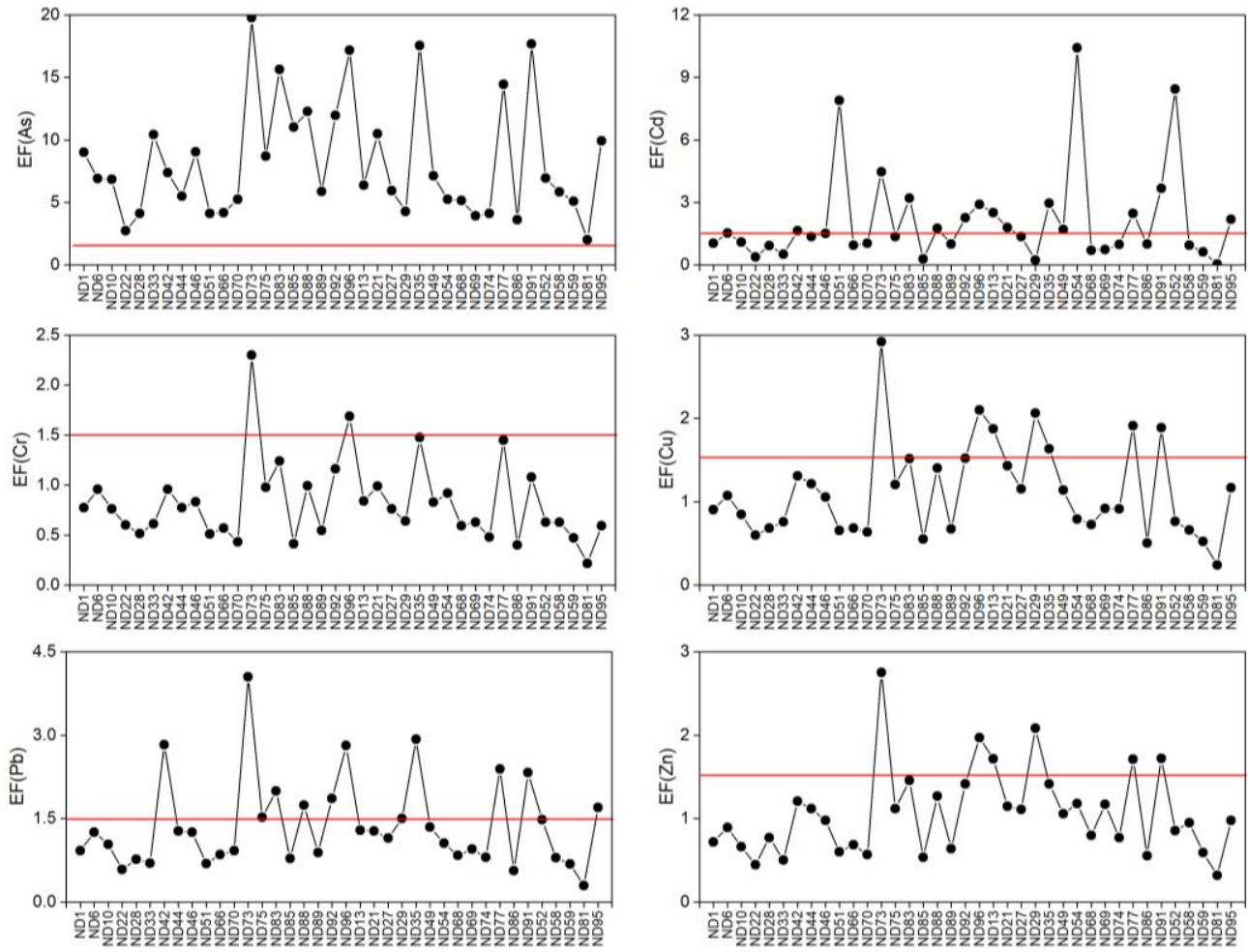

Figure 10. Spatial variations of EF values of the agricultural soil in Nam Dinh province

According to land use type and spatial distribution, the smallest mean EF values occurred in aquaculture soil samples, lower 1.4 to 2 times than its in paddy and cereal soil. There is no significant difference in the degree of metal contamination between paddy soil and cereal soil samples. The EF values of As show pronounced higher values in Nghia Hung, Hai Hau, and Nam Truc districts, these sites are localed near industrial zone and traditional handicraft village (e.g. ND88 near to the Thinh Long industrial zone; ND91 and ND92 near to Quy Nhat industrial zone, ND33 near to Dong Quy metal smelting village). The EFs (Cd) show higher in Hai Hau, Nghia Hung and Giao Thuy districts (ND51, ND52, ND54, ND73, ND83, ND92, ND96).

\section{Sources of heavy metal in agricultural soil}

Correlation analysis is not only an effective approach to reveal the relationships between heavy metals and soil physicochemical properties, but also an operative way to understand the controlling factors of heavy metals as well as their possible sources 
(Chai et al., 2015). Correlation analysis reveals diverse relationships between particle size, TOC and $\mathrm{pH}$ of soil and heavy metal contents (Table 6).

Table 5. Enrichment factor (EF) of heavy metals for agricultural soil in Nam Dinh province

\begin{tabular}{c|c|c|c|c|c|c|c}
\hline Land use type & Parameter & $\mathbf{E F}(\mathbf{A s})$ & $\mathbf{E F}(\mathbf{C d})$ & $\mathbf{E F}(\mathbf{C r})$ & $\mathbf{E F}(\mathbf{C u})$ & $\mathbf{E F}(\mathbf{P b})$ & $\mathbf{E F}(\mathbf{Z n})$ \\
\hline & Mean & 8.89 & 1.86 & 0.88 & 1.12 & 1.44 & 1.02 \\
Paddy soil & Max & 19.77 & 7.90 & 2.30 & 2.92 & 4.05 & 2.75 \\
$\mathrm{n}=20$ & Min & 2.74 & 0.28 & 0.41 & 0.55 & 0.58 & 0.45 \\
& SD & 4.65 & 1.75 & 0.46 & 0.59 & 0.90 & 0.57 \\
\hline \multirow{4}{*}{ Cereal soil } & Mean & 8.15 & 2.35 & 0.85 & 1.30 & 1.42 & 1.26 \\
$\mathrm{n}=12$ & Max & 17.68 & 10.41 & 1.47 & 2.06 & 2.93 & 2.08 \\
& Min & 3.63 & 0.22 & 0.40 & 0.50 & 0.56 & 0.55 \\
& SD & 5.17 & 2.62 & 0.33 & 0.53 & 0.71 & 0.44 \\
\hline \multirow{4}{*}{ Aquaculture soil } & Mean & 5.96 & 2.45 & 0.51 & 0.67 & 0.99 & 0.74 \\
n =6 & Max & 9.93 & 8.44 & 0.63 & 1.17 & 1.70 & 0.98 \\
& Min & 2.03 & 0.05 & 0.22 & 0.24 & 0.29 & 0.32 \\
& SD & 2.87 & 3.44 & 0.17 & 0.34 & 0.58 & 0.28 \\
\hline \multirow{4}{*}{ All samples } & Mean & 8.09 & 2.03 & 0.82 & 1.09 & 1.34 & 1.04 \\
n =38 & Max & 19.77 & 10.41 & 2.30 & 2.92 & 4.05 & 2.75 \\
& Min & 2.03 & 0.05 & 0.22 & 0.22 & 0.29 & 0.32 \\
& SD & 4.62 & 2.24 & 0.41 & 0.57 & 0.80 & 0.52 \\
\hline
\end{tabular}

Table 6. Statistical results from principal component analysis (PCA)

\begin{tabular}{|c|c|c|c|c|c|c|c|c|c|c|c|c|c|}
\hline & As & Cd & $\mathrm{Cr}$ & $\mathbf{C u}$ & $\mathbf{P b}$ & $\mathrm{Zn}$ & Mn & Al & pH & TOC & Sand & Silt & Clay \\
\hline As & 1.00 & 0.02 & 0.64 & 0.65 & 0.59 & 0.52 & -0.02 & 0.41 & -0.26 & 0.45 & -0.27 & 0.33 & 0.17 \\
\hline $\mathrm{Cd}$ & & 1.00 & 0.14 & 0.14 & 0.14 & 0.16 & 0.08 & 0.11 & 0.15 & -0.01 & 0.25 & -0.24 & -0.24 \\
\hline $\mathrm{Cr}$ & & & 1.00 & 0.82 & 0.73 & 0.74 & -0.05 & 0.40 & -0.46 & 0.52 & -0.34 & 0.35 & 0.30 \\
\hline $\mathrm{Cu}$ & & & & 1.00 & 0.83 & 0.91 & -0.18 & 0.34 & -0.48 & 0.58 & -0.40 & 0.43 & 0.34 \\
\hline $\mathrm{Pb}$ & & & & & 1.00 & 0.80 & -0.13 & 0.24 & -0.24 & 0.46 & -0.42 & 0.45 & 0.36 \\
\hline $\mathrm{Zn}$ & & & & & & 1.00 & -0.01 & 0.37 & -0.32 & 0.54 & -0.33 & 0.35 & 0.28 \\
\hline \multicolumn{14}{|c|}{ Rotated loading matrix $($ VARIMAX Gamma $=\mathbf{1 . 0 0 0})$} \\
\hline & $P C 1$ & $P C 2$ & PC3 & & & & & & & & & & \\
\hline $\mathrm{Cu}$ & 0.91 & 0.16 & -0.19 & & & & & & & & & & \\
\hline $\mathrm{Zn}$ & 0.90 & 0.12 & -0.03 & & & & & & & & & & \\
\hline $\mathrm{Cr}$ & 0.87 & 0.10 & -0.14 & & & & & & & & & & \\
\hline $\mathrm{Pb}$ & 0.84 & 0.24 & 0.00 & & & & & & & & & & \\
\hline As & 0.75 & 0.06 & -0.07 & & & & & & & & & & \\
\hline $\mathrm{Al}$ & 0.55 & -0.53 & -0.13 & & & & & & & & & & \\
\hline Sand & -0.27 & -0.94 & 0.14 & & & & & & & & & & \\
\hline Clay & 0.20 & 0.93 & -0.11 & & & & & & & & & & \\
\hline Silt & 0.31 & 0.91 & -0.15 & & & & & & & & & & \\
\hline $\mathrm{Cd}$ & 0.27 & -0.35 & 0.28 & & & & & & & & & & \\
\hline $\mathrm{pH}$ & -0.33 & -0.09 & 0.86 & & & & & & & & & & \\
\hline Mn & 0.06 & -0.11 & 0.80 & & & & & & & & & & \\
\hline TOC & 0.57 & 0.17 & -0.58 & & & & & & & & & & \\
\hline Eigenvalue & 5.64 & 2.64 & 1.48 & & & & & & & & & & \\
\hline$\%$ total variance & 43.40 & 20.33 & 11.34 & & & & & & & & & & \\
\hline$\%$ cumulative & 43.40 & 63.74 & 75.08 & & & & & & & & & & \\
\hline
\end{tabular}

Bold type indicates significance at $\mathrm{p}<0.05$ 
Based on Pearson's correlation coefficients $\mathrm{Cr}, \mathrm{Cu}, \mathrm{Pb}$, and $\mathrm{Zn}$ were found significantly positively correlated with each other $(\mathrm{P}<0.01)$. A highly positive correlation $(\mathrm{P}<0.01)$ was found between $\mathrm{Cu}$ and $\mathrm{Zn}(\mathrm{r}=0.91), \mathrm{Cu}$ and $\mathrm{Pb}(\mathrm{r}=0.83)$, $\mathrm{Cu}$ and $\mathrm{Cr}(\mathrm{r}=0.82), \mathrm{Pb}$ and $\mathrm{Zn}(\mathrm{r}=0.80), \mathrm{Cr}$ and $\mathrm{Pb}(\mathrm{r}=0.73), \mathrm{Cr}$ and $\mathrm{Zn}(\mathrm{r}=0.74)$, indicating their similar sources. Arsenic has a positive correlation $(\mathrm{P}<0.01)$ with $\mathrm{Cr}$, $\mathrm{Cu}, \mathrm{Pb}$, and $\mathrm{Zn}$, but these correlation coefficients were relatively weak, i.e., As and $\mathrm{Cr}$ $(r=0.64)$, As and $\mathrm{Cu}(\mathrm{r}=0.65)$, As and $\mathrm{Pb}(\mathrm{r}=0.59)$, As and $\mathrm{Zn}(\mathrm{r}=0.52)$. Cadmium does not show correlations with any heavy metals in agricultural soil, suggesting $\mathrm{Cd}$ perhaps has different sources or geochemical behaviour.

Soil $\mathrm{pH}$ does not show correlations with $\mathrm{As}, \mathrm{Cd}$ and $\mathrm{Pb}$, however, it shows a negative correlation with $\mathrm{Cr}, \mathrm{Cu}$, and $\mathrm{Zn}$ (Table 6), indicating that neutral soil contains less heavy metals (Chai et al., 2015; Kua et al., 1983; Manta et al., 2002). TOC, Al and silt percentage show a weakly positive correlation with $\mathrm{As}, \mathrm{Cr}, \mathrm{Cu}, \mathrm{Pb}$, and $\mathrm{Zn}(\mathrm{p}<0.01)$, indicating that these heavy metals are controlled by the contents of organic carbon as well as proportions of finer grain size fractions. Since $\mathrm{Cd}$ is not correlated with TOC, $\mathrm{Al}$, and grain size, there exits other factor influencing its contents, which most probably is anthropogenic input.

The results are illustrated in the dendrogram in Figure 11, two distinct clusters are identified. The first cluster includes $\mathrm{Cu}, \mathrm{Zn}, \mathrm{Pb}, \mathrm{Cr}, \mathrm{As}$ and $\mathrm{TOC}$, while $\mathrm{Cd}$ cluster into the second group.

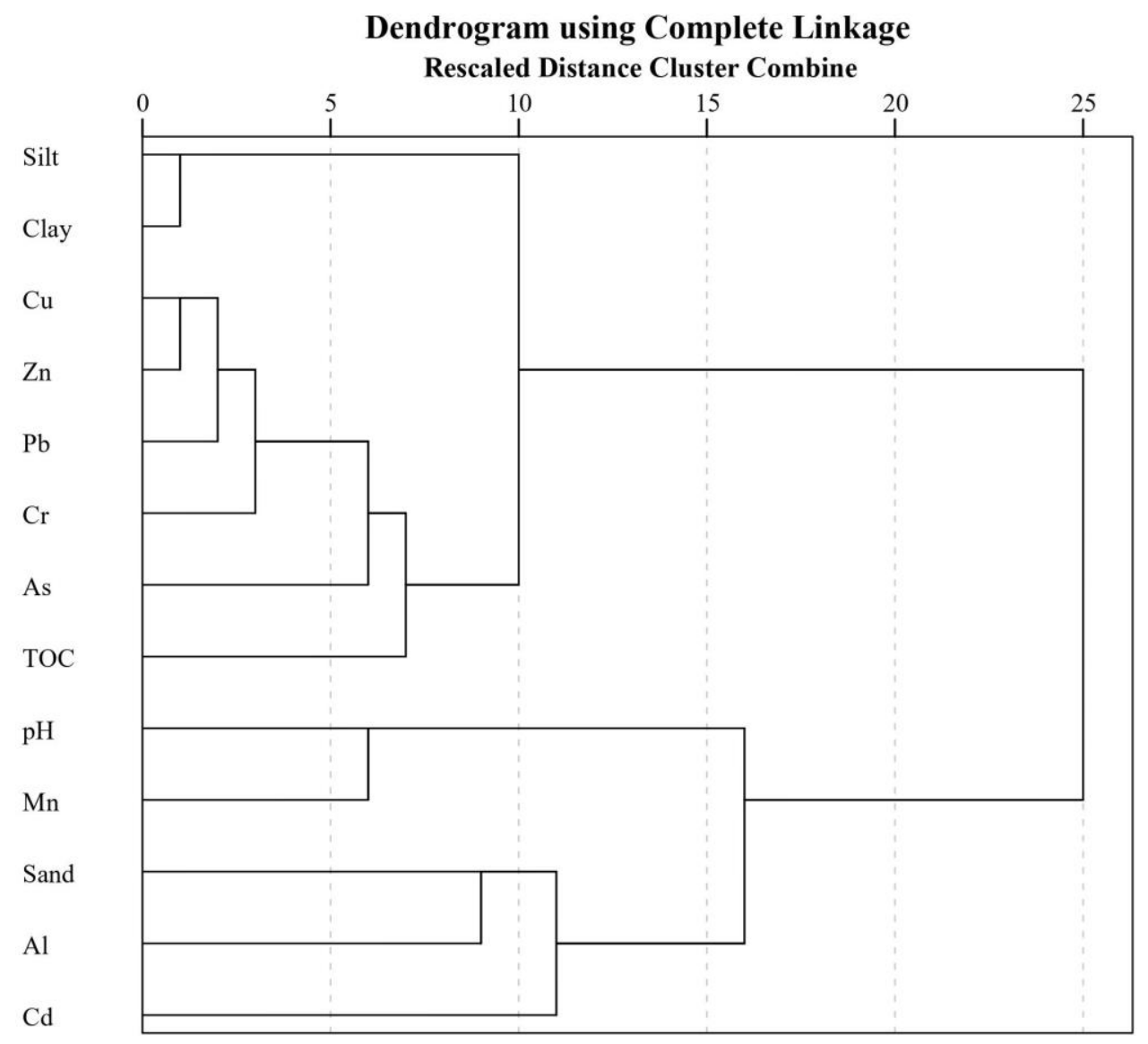

Figure 11. Hierarchical cluster analysis among particle size and geochemical compositions in topsoil of agricultural soil in Nam Dinh province 
The results of PCA are presented in Table 6 and Figure 12. The extracted four components with eigen values $>1$ explain $75.08 \%$ of total variance. The first principal component (PC1) accounts for $43.40 \%$ of total variance, showing high positive loadings of $\mathrm{Cu}(0.91), \mathrm{Zn}(0.90), \mathrm{Cr}(0.87), \mathrm{Pb}(0.85)$, As (0.75), and medium loading of TOC (0.57) and $\mathrm{Al}(0.55)$. The second principal component (PC2) with a variance loading of $20.33 \%$ is dominated by the loading clay $(0.94)$ and silt $(0.91)$. The third principal component (PC3) is a less important component, accounting for 11.43 of the total variances, showing positive loading of $\mathrm{Mn}(0.80), \mathrm{pH}(0.86)$ and $\mathrm{Cd}(0.28)$.

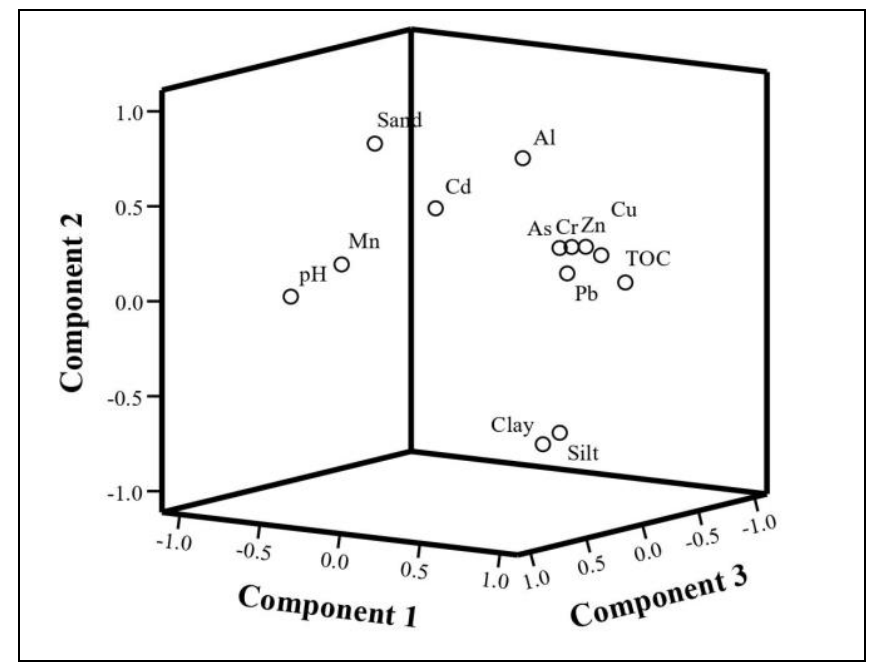

Figure 12. Principal component analysis loading plots for rotated components of heavy metals and soil properties in Nam Dinh province

According to the results from cluster and PCA analyses, two groups of elements can be identified: group 1 includes $\mathrm{As}, \mathrm{Cu}, \mathrm{Zn}, \mathrm{Pb}$ and $\mathrm{Cr}$, which show affinity with TOC and clay minerals; group 2 include $\mathrm{Cd}$ only.

Group 1 can be further subdivided into three sub-clusters. The first one sub-cluster includes Cr element. Since the concentration of $\mathrm{Cr}$ in the soil $(10.68-57.20 \mathrm{mg} / \mathrm{kg})$ was less than its concentration in UCC $(85 \mathrm{mg} / \mathrm{kg})$ and enrichment factor values of Cr were less than 1.5 , it can state that $\mathrm{Cr}$ originated from natural sources. In addition, a previous study suggested that natural weathering processes are a major factor dominating the amount and distribution of $\mathrm{Cr}$ in surface sediments of the Red River, Vietnam, and it has a non-anthropogenic origin in Ba Lat estuary (Nguyen et al., 2016b).

The second sub-cluster includes As. The element As has a weak correlation with other heavy metals in this group, and it has enrichment factor values higher than 2 . It indicated that this element has industrial and domestic sources. The main reason for the high enrichment factor values of As could be that the groundwater at these sites contains higher As level, which is commonly used to irrigate agricultural soil. The geology of Red delta shows similarity with the Ganges-Brahmaputra, where high As levels in the groundwater have been reported (Agusa et al., 2005, 2006; Berg et al., 2001, 2007; Chander et al., 2004; Nguyen et al., 2008). The same result was reported in agricultural soils in the Pear River, China (Chai et al., 2004; Huang et al., 2011). Element As was also found in pig and chicken manure, which are often used on the soil as a fertilizer (Zarcinas et al., 2005; Duan et al., 2016; Wang et al., 2019a). In contrast, 
increased industrial activities, such as chemical and fertilizer production as well as manufacturing in traditional handicraft villages (e.g. metal smelting and processing and painting), might have become additional sources of pollution in recent years.

The third sub-cluster includes $\mathrm{Cu}, \mathrm{Pb}$ and $\mathrm{Zn}$. These heavy metals have mean enrichment factor values less than 1.5 and they have a close correlation with TOC, silt and $\mathrm{Al}$. These factors indicate a natural origin of $\mathrm{Cu}, \mathrm{Pb}$ and $\mathrm{Zn}$.

The second group indicates for $\mathrm{Cd}$. Element $\mathrm{Cd}$ pollution was possibly caused by anthropogenic wastes, including sewage sludge, wastewater and/or fertilizers and pesticides.

As mentioned above, the EF values of Cd show higher values in Nghia Hung and Giao Thuy, these two districts are coastal districts of Nam Dinh province. These sites are located near the dike, high way, ecotourism zone, and industrial zone (e.g. ND95 near to Thinh Long ecotourism zone, ND51, ND52, ND54 near to the dike). Trinh and Shin (2004) also pointed out that, possible sources of Cd in Red River delta were irrigation water contaminated by inflow of improperly disposed wastewater, sewage sludge that was incorporated in the agricultural soil as an amendment, and vehicle tires.

\section{Conclusions}

Heavy metal contents are higher in soils of paddy fields and cereal fields, but lower in aquaculture soil.

According to cluster and PCA analyses, heavy metals can be grouped into two groups. Elements $\mathrm{Cu}, \mathrm{Pb}, \mathrm{Cd}$, As and $\mathrm{Zn}$ have similar geochemical behaviours while $\mathrm{Cd}$ is different from them.

According to enrichment factor, elements $\mathrm{Cr}$ are mainly from natural source, while $\mathrm{Cd}$ and $\mathrm{As}$ have a significant anthropogenic input. Elements $\mathrm{Cu}, \mathrm{Pb}$ and $\mathrm{Zn}$ have a mixed source.

Hot spots with high levels of As and Cd pollution are normally located next to industrial zones and traditional handicraft villages. These hotspots should be managed properly in terms of human health.

The effect of land use type on heavy metal concentrations will be discussed deeply in future studies.

Acknowledgments. The authors would like to acknowledge the project: "Effect of landscape differentiation on heavy metal distribution in agricultural land in Hai Hau district, Nam Dinh province", belonging to the Sciences on Earth research field in Vietnam Academy of Science and Technology; Code: VAST05/18-19.

\section{REFERENCES}

[1] Agusa, T., Inoue, S., Kunito, T., Kubota, R., Minh, T. B., Trang, P. T. K., Subramanian, A., Iwata, H., Viet, P. H., Tanabe, S. (2005): Widely-distributed arsenic pollution in groundwater in the Red River Delta, Vietnam. - Biomedical Research on Trace Elements 16(4): 296-298.

[2] Agusa, T., Kunito, T., Fujihara, J., Kubota, R., Minh, T. B., Trang, P. T. K., Iwata, H., Annamali, S., Viet, P. H., Tanabe, S. (2006): Contamination by arsenic and other trace elements in tube-well water and its risk assessment to humans in Hanoi, Vietnam. Environmental Pollution 139(1): 95-106. 
[3] Berg, M., Tran, H. C., Nguyen, T. C., Viet, P. H., Schertenleib, R., Giger, W. (2001): Arsenic contamination of groundwater and drinking water in Vietnam: a human health threat. - Environmental Science and Technology 35(13): 2621-2626.

[4] Berg, M., Stengel, C., Trang, P. T. K., Viet, P. H., Sampson, M. L., Leng, M., Samreth, S., Fredericks, D. (2007): Magnitude of arsenic pollution in the Mekong and Red River Deltas-Cambodia and Vietnam. - Science of the Total Environment 372(2-3): 413-425.

[5] Chai, S. W., Wen, Y. M., Wei, X. G., Zhang, Y. N., Dong, H. Y., Chen, Y. J. (2004): Heavy metal content characteristics of agricultural soils in the Pearl River Delta. - Acta Scientiarum Naturalium Universitatis Sunyatseni 43(4): 90-94 (in Chinese with English abstract).

[6] Chai, Y., Guo, J., Chai, S. L., Cai, J., Xue, L. F., Zhang, Q. W. (2015): Source identification of eight heavy metals in grassland soils by multivariate analysis from the Baicheng-Songyuan area, Jilin Province, Northeast China. - Chemosphere 134: 67-75.

[7] Chander, B., Nguyen, T. P. T., Nguyen, Q. H. (2004): Random survey of arsenic contamination in tube-well water of 12 provinces in Vietnam and initially human health arsenic risk assessment through food chain. - Workshop of Science and Technology Relating to Arsenic Contamination, 16 November, Hanoi, Vietnam.

[8] Cheng, S. P. (2003): Heavy metal pollution in China: origin, pattern and control. Environmental Science and Pollution Research 10: 192-198.

[9] Dao, H. Q., Nguyen, D. H. (2000): A summary of the existing environment state of craft oriented villages in Nam Dinh Province. - International Workshop "Environment protection, community health for sustainable development of craft manufacturing settlements in Nam Dinh", October 26-27, Nam Dinh, Vietnam (in Vietnamese).

[10] Dao, H. Q., Le, D. N., Dao, M. T. (2005): Water problem in the strategy for socioeconomic development of Nam Dinh province. - Journal of Geology B/25: 3-8. HaNoi.

[11] Dragović, S., Mihailović, N. (2009): Analysis of mosses and topsoils for detecting sources of heavy metal pollution: multivariate and enrichment factor analysis. Environmental Monitoring and Assessment 157: 383-390.

[12] Duan, G. L., Zhang, H. M., Shen, Y. Q., Li, G., Wang, H., Cheng, W. D. (2016): Mitigation of heavy metal accumulation in rice grain with silicon in animal manure fertilized field. - Environmental Engineering and Management Journal 15(10): 22232229.

[13] Elsorogy, A. S., Youssef, M., Alkahtany, K., Alotaiby, N. (2016): Assessment of arsenic in coastal sediments, seawaters and molluscs in the Tarut Island, Arabian Gulf, Saudi Arabia. - Journal of African Earth Sciences 113: 65-72.

[14] Han, Y. M., Du, P. X., Cao, J. J., Eric, S. P. (2006): Multivariate analysis of heavy metal contamination in urban dusts of Xi'an, central China. - Science of The Total Environment 355(1-3): 176-186.

[15] Hou, Q. Y., Yang, Z. F., Ji, J. F., Yu, T., Chen, G. G.., Li, J., Xia, X. Q., Zhang, M., Yuan, X. Y. (2014): Annual net input fluxes of heavy metals of the agro-ecosystem in the Yangtze River delta, China. - Journal of Geochemical Exploration 139: 68-84.

[16] Hu, Y and Gao, S. (2008): Upper crustal abundances of trace elements: a revision and update. - Chemical Geology 253(3-4): 205-221.

[17] Huang, G. X., Sun, J. C., Zhang, Y., Jing, J. H., Zhang, Y. X., Liu, J. T. (2011): Distribution of arsenic in sewage irrigation area of Pearl River Delta, China. - Journal of Earth Science 22(3): 396-410.

[18] Huang, Y., Deng, M. H., Wu, S. F., Japenga, J., Li, T. Q., Yang, X., He, Z. L. (2018): A modified receptor model for source apportionment of heavy metal pollution in soil. Journal of Hazardous Materials 354: 161-169.

[19] Joern, K., Steffen, G., Le, T. L. (2013): Province Nam Dinh - an analysis for a future integrated water resource management. - http://www.idm.gov.vn (accessed on 15 June 2019). 
[20] Le, T. L., Kasbohm, J., Dao, H. Q., Tran, T. H., Schafmeister, M. T. (2003): Geochemical characterization pathways "Production Site - Water - Sediment -Soil - Food - Residents" as basis for an in-situ treatment system in the craft-settlements of Nam Dinh Province. Journal of Geology B/21: 32-41. Ha Noi.

[21] Li, F., Zhang, J. D., Liu, W. C., Liu, J. A., Huang, J. H., Zeng, G. M. (2018): An exploration of an integrated stochastic-fuzzy pollution assessment for heavy metals in urban topsoil based on metal enrichment and bioaccessibility. - Science of The Total Environment 644: 649-660.

[22] Loska, K., Wiechula, D. (2003): Application of principle component analysis for the estimation of source of heavy metal contamination in surface sediments from the Rybnik Reservoir. - Chemosphere 51(8): 723-733.

[23] Loska, K., Wiechula, D., Korus, I. (2004): Metal contamination of farming soils affected by industry. - Environment International 30(2): 159-165.

[24] Lu, A. X., Wang, J. H., Qin, X. Y., Wang, K. Y., Han, P., Zhang, S. Z. (2012): Multivariate and geostatistical analyses of the spatial distribution and origin of heavy metals in the agricultural soils in Shunyi, Beijing, China. - Science of The Total Environment 425: 66-74.

[25] Luo, W., Lu, Y. L., Giesy, J. P., Wang, T. Y., Shi, Y. J., Wang, G., Xing, Y. (2007): Effects of land use on concentrations of metals in surface soils and ecological risk around Guanting Reservoir, China. - Environmental Geochemistry and Health 29(6): 459-71.

[26] Manta, D. S., Angelone, M., Bellanca, A., Neri, R., Sprovieria, M. (2002): Heavy metals in urban soils: a case study from the city of Palermo (Sicily), Italy. - Science of the Total Environment 300(1-3): 229-243.

[27] Marrugo-Negrete, J., Pinedo-Hernández, J., Díez, S. (2017): Assessment of heavy metal pollution, spatial distribution and origin in agricultural soils along the Sinú River Basin, Colombia. - Environmental Research 154: 380-388.

[28] Nabulo, G., Young, S. D., Black, C. R. (2010): Assessing risk to human health from tropical leafy vegetables grown on contaminated urban soils. - Science of the Total Environment 408(22): 5338-5351.

[29] Nguyen, M. P., Yumei, K., Katsutoshi, S., Kozo, I., Chu, N. K., Nguyen, V. N., Le, T. S. (2008): Arsenic contents and physicochemical properties of agricultural soils from the Red River Delta, Vietnam. - Soil Science and Plant Nutrition 54(6): 846-855.

[30] Nguyen, T. T. H., Zhang, W. G., Li, Z., Li, J., Ge. C., Liu, J. Y., Bai, X. X., Feng, H., Yu, L. Z. (2016a): Assessment of heavy metal pollution in Red River surface sediments, Vietnam. - Marine Pollution Bulletin 113(1-2): 513-519.

[31] Nguyen, V. T., Ozaki, A., Nguyen, H. T., Nguyen, D. A., Tran, T. Y., Kurosawa (2016b): Arsenic and Heavy Metal Contamination in Soils under different land use in an Estuary in Northern Vietnam. - International Journal of Environmental Research and Public Health 13(11): 1091.

[32] Nguyen, V. T., Yasuhito, O., Tatsuro, A., Phong, K. T., Nobuhiko, N., Akinori, O., Yoshihiro, K., Ryosuke, K., Masato, M., Kiyoshi, K. (2018): Chemical speciation and bioavailability concentration of arsenic and heavy metals in sediment and soil cores in estuarine ecosystem, Vietnam. - Microchemical Journal 139: 268-277.

[33] Phan, Q. H., Tran, T. H. T. (2016): Đánh giá tính chất và mức độ ô nhiễm đất nông nghiệp thuộc lưu vực sông Nhuệ tại huyện Duy Tiên, tỉnh Hà Nam. - Tạp chí Khoa học Nông nghiệp Việt Nam 14(11): 1741-1752 (in Vietnamese).

[34] Salomons, W., Förstner, U. (1984): Metals in the Hydrocycle. - Springer, Berlin.

[35] Schropp, S. J., Windom, H. L. (1988): A Guide to the Interpretation of Metal Concentrations in Estuarine. - Florida Department of Environmental Protection, USA. http://www.dep.state.fl.us/Waste/quick_topics/publications/documents/sediment/estuarine .pdf (accessed 01.07.10).

[36] Sinex, S. A., Wright, D. A. (1988): Distribution of trace metals in the sediments and biota of Chesapeake Bay. - Marine Pollution Bulletin 19(9): 425-431. 
[37] Sutherland, R. A. (2000): Bed sediment-associated trace metals in an urban stream, Oahu, Hawaii. - Environmental Geology 39: 611-627.

[38] Taylor, S. R., McLennan, S. M. (1995): The geochemical evolution of the continental crust. - Reviews of Geophysics 33(2): 241-265.

[39] Trinh, Q. H., Shin, I. W. (2004): Cadmium status of some soils and sewage sludge in red river delta of Vietnam. - Journal of the Faculty of Agriculture, Kyushu University 49(1): 149-155.

[40] Vodyanitskii, Y. N. (2013): Contamination of soils with heavy metals and metalloids and its ecological hazard (analytic review). - Eurasian Soil Science 46: 793-801.

[41] Wang, P. C., Li, Z. G., Bi, X. Y., Ning, Y. Q., Yang, S. C., Yang, X. J. (2019a): Apportionment of sources of heavy metals to agricultural soils using isotope fingerprints and multivariate statistical analyses. - Environmental Pollution 249: 208-216.

[42] Wang, S., Cai, L. M., Wen, H. H., Luo, J., Wang, Q. S., Liu, X. (2019a): Spatial distribution and source apportionment of heavy metals in soil from a typical country-level city of Guangdong Province, China. - Science of the Total Environment 655: 92-101.

[43] Wu, C. F., Zhang, L. M. (2010): Heavy metal concentrations and their possible sources in paddy soils of a modern agricultural zone, southeastern China. - Environmental Earth Sciences 60: 45-56.

[44] Wu, J., Lu, J., Li, L. M., Min, X. Y., Luo, Y. M. (2018): Pollution, ecological-health risks, and sources of heavy metals in soil of the northeastern Qinghai-Tibet Plateau. Chemosphere 201: 234-242.

[45] Zarcinas, B. A., McLaughlin, M., Ha, P. Q., Cozens, G. (2005): Heavy metal research in Vietnam: an overview. - Proceedings of 8th International Conference on the Biogeochemistry of Trace Elements, April 2005, Adelaide, Australia.

[46] Zhang, J., Liu, C. L. (2002): Riverine composition and estuarine geochemistry of particulate metals in China-weathering features, anthropogenic impact and chemical fluxes. - Estuarine Coastal and Shelf Science 54(6): 1051-1070. 